\title{
Evaluation of the Cultural Elements in the Textbook "Genki I: An Integrated Course in Elementary Japanese"
}

\author{
Onur Er \\ Correspondence: Onur Er, Faculty of Education, Kafkas University, Kars, Turkey. \\ Received: July 12, $2017 \quad$ Accepted: August 17, $2017 \quad$ Online Published: August 23, 2017 \\ doi:10.11114/jets.v5i9.2532 URL: https://doi.org/10.11114/jets.v5i9.2532
}

\begin{abstract}
This study aims to examine the textbook "Genki I: An Integrated Course in Elementary Japanese" in terms of cultural elements. The data of this qualitative research were collected by means of the document review method. Content analysis, one of the qualitative analysis techniques, was used in the evaluation of the research data. A second coding was carried out by a second researcher to ensure the reliability of the study. The categories in the study were formed in the line of the cultural product, thought and behavior classifications developed by Tomalin \& Stempleski (1993). In addition, the tools for cultural instruction, as taught by Qu (2010), Frank (2013), Peterson \& Coltrane (2003), have helped to create the relevant codes.

In comparison of the cultural elements in the textbook "Genki I: an Integrated Course in Elementary Japanese", this study found that the textbook emphasizes more on the elements related to behavioral dimension of the culture, but does not give much room for the elements related to belief dimension. Also, the textbook "Genki I: an Integrated Course in Elementary Japanese" was observed to use the device of "describing and explaining the culture", at most.
\end{abstract}

Keywords: cultural elements, foreign language education, textbook, qualitative research

\section{Introduction}

Language is a communication tool that stands out with its complicated structure. This communication tool offers a variety of possibilities for the individual to understand the environment, socialize and gain self-confidence. However, in order for the individual to have the possibilities offered by the language, he/she must firstly be able to use the language effectively. The effective way to use the language passes through understanding its culture.

The language does not only contain grammar, phonology and lexicology, but also contains certain features and characteristics of the relevant culture (Çakır, 2006; Qu, 2010). So, one of the goals of language teaching has been to create cultural awareness of the language learning individuals. "Learners' cultural awareness can be shown as their perceptions and understandings of both the target language culture and their own culture" (Nguyen, 2017, p. 149). Genç $\&$ Bada (2005) found that the training given in the culturally targeted language contributes significantly to language skills and cultural awareness of the language learning individuals, profession of the target language teaching person, and change of attitudes towards both the target language and society. Bada (2000) asserts that if language teaching and culture are separated, the individual studying a language will be prevented from learning of the relevant community's characteristics. The strong relationship between language and culture has also reflected in the literature. There are a great number of studies on culture, especially in the second language education (Akpınar \& Mete, 2013; C. Alyılmaz, 2010; Bada, 2000; Byram, Gribkova \& Starkey, 2002; Castro \& Sercu, 2005; Cortazzi \& Jin, 2000; Çakır, 2006; Frank, 2013; Genç \& Bada, 2005; Peterson \& Coltrane, 2003; Salazar \& Carballo, 2011, Qu, 2010, Vrbová, 2006).

The words in a language help an individual understand the relevant culture. Mert, S. Alyılmaz, Bay \& Akbaba (2009) argue that a culture can be depicted with reference to vocabulary of the language, excess, lack or absence of the words related to some concepts, and perception types of the concepts. Tomalin \& Stempleski (1993) set out the cultural elements as follows: 


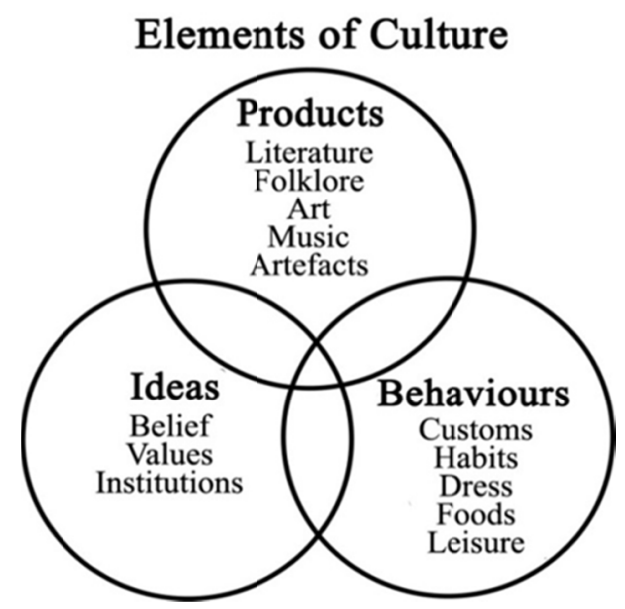

Figure 1. Elements of Culture (Tomalin and Stempleski, 1993, p. 7)

As seen in Figure 1, Tomalin \& Stempleski (1993) evaluated the culture under three dimensions: product, thought and behavior. Sub-elements of the product dimension include literature, folklore, art, music and artefacts, while sub-elements of the thought dimension is introduced as beliefs, values and institutions. Finally, sub-elements of the behavior dimension consist of customs, habits, dress, foods and leisure.

Teacher is the person who can express cultural elements and make his/her students feel it. Therefore, the teacher has a duty to ensure the students to establish a relationship between their own culture and the target language's culture (Byram, Gribkova \& Starkey, 2002, Castro \& Sercu, 2005). However, the teacher must use various materials to fulfill this task. In this regard the teacher makes use of the relevant textbook, at first. Cortazzi \& Jin (2000) identifies the textbook as one of the dimensions of the cultural awareness-building process in language teaching.

Many books related to Japanese and Japanese culture as well as Chinese and Chinese culture has been examined in the relevant literature (Wierzbicka, 2006). Wang (2006) stated that the increase in the number of textbooks written for Chinese teaching leads to confusion in minds. Therefore, the extra amount of textbooks written for a second language teaching places an extra responsibility on a language teacher. Because the teacher should be able to choose the textbook that will be most useful to his/her students. For this reason, the researches deeply examining the textbooks should guide the teachers. Examining the Genki I textbook in a cultural perspective in details, this study tries to provide the teachers with an idea about choosing a textbook.

This study aims to examine the textbook "Genki I: An Integrated Course in Elementary Japanese" in terms of cultural elements. The cultural elements in the textbook of Genki I: an Integrated Course in Elementary Japanese were evaluated within the scope of this present study. The cultural elements created by Tomalin \& Stempleski (1993) were taken as basis in the evaluation of the cultural elements stated in the textbook in question.

The study seeks to answer the following questions:

How does product dimension of the culture take place in in the textbook "Genki I: an Integrated Course in Elementary Japanese"?

How does thought dimension of the culture take place in in the textbook "Genki I: an Integrated Course in Elementary Japanese"?

How does behavior dimension of the culture take place in in the textbook "Genki I: an Integrated Course in Elementary Japanese"?

What are the devices used to create cultural awareness in the textbook "Genki I: an Integrated Course in Elementary Japanese"?

\section{Method}

\subsection{Research Model}

This study was performed in screening model and designed according to the qualitative method in order to evaluate the cultural elements in the textbook of Genki I: an Integrated Course in Elementary Japanese. Qualitative research can be defined as a research following qualitative process in which the qualitative data collection methods such as observation, interview and document analysis are used, and the relevant phenomena and events are presented in a realistic and holistic manner in their natural environments (Yıldırım \& Şimşek, 2008, p. 39). 


\subsection{The Examined Textbook}

The textbook "Genki I: an Integrated Course in Elementary Japanese" (English parts and images) was examined in the present study. This textbook aims to teach Japanese as a second language at the beginner level. There are 12 chapters in the textbook, and cultural notes at the end of each chapter.

\subsection{Data Collection}

The research data were collected from the textbook of Genki I: an Integrated Course in Elementary Japanese, using the document review method as one of the qualitative data collection methods. "Document review includes analysis of the written materials that contain information about the facts or phenomena targeted for investigation" (Yıldırım \& Şimşek, 2008, p. 187).

\subsection{Data Analysis}

Content analysis from the qualitative analysis techniques was used in evaluation of the research data. "The main goal in content analysis is to reach the concepts and associations that can explain the collected data. The basic process in content analysis is to put together similar data within the framework of specific concepts and themes, and interpret them in a way that the reader can understand" (Yıldırım \& Şimşek, 2008, p 227). The textbook was read in the research and then the coding was done in a general framework. Later, the categories, themes and codes were created based on the cultural elements generated by Tomalin \& Stempleski (1993) and the cultural awareness devices specified by Qu (2010), Frank (2013), Peterson \& Coltrane (2003). Images in the textbook have also been analyzed in terms of culture. Yildırım \& Şimşek (2008) and Merriam (2013) stated that visual materials are among the document types, so they can be used in qualitative researches.

The codes and themes of the two researchers were compared in order to ensure reliability of the research and confirm whether the codes contained in the obtained themes have corresponded to the themes in question. Miles \& Huberman's (1994) Reliability $=$ (number of agreements / total number of agreements + disagreements) $x 100$ formula was used to ensure the reliability of the data obtained by the content analysis method applied in the research. The reliability among the researchers was found to be .93 using this formula. The codes leading a disagreement between the two researchers were discussed and then placed under appropriate themes.

\section{Results}

The categories, themes and codes obtained from the textbook that was examined in the direction of the research questions are presented in this section by using the following tables.

Table 1. Themes and codes of the cultural elements in product dimension of the culture in genki I textbook

\begin{tabular}{l|l}
\hline Genki I: An Integrated Course in Elementary Japanese \\
\hline Themes and Codes & Themes and Codes by the Textbook Section \\
\hline Alphabet & Section including Alphabet Theme \\
Hiragana & Japanese Writing System \\
Kanji & Japanese Writing System \\
Katakana & Japanese Writing System \\
\hline Architecture & Section including Architecture Theme \\
Japanese Houses & Culture Notes \\
Shurei Gate on 2,000-yen bill & Culture Notes \\
\hline Folklore & Section including Folklore Theme \\
Japanese Folktale & The Folktale Kasajizo \\
Kabuki Theater & Kabuki and Culture Notes \\
Puppet Theater & Culture Notes \\
Humorous Storytelling & Culture Notes \\
Masked Musical Drama & Culture Notes \\
\hline Literature & Section including Literature Theme \\
A portrait of Ichiyoo Higuchi on 5,000-yen bill & Culture Notes \\
\hline Philosophy & Section including Philosophy Theme \\
A portrait of Yukichi Fukuzawa on 10,000-yen bill & Culture Notes \\
\hline Science & Section including Science Theme \\
A portrait of Hideyo Noguchi on 10,000-yen bill & Culture Notes \\
\hline Sport & Sections including Sports Theme \\
Sumo Wrestling & Culture Notes \\
Judo & Culture Notes \\
Japanese Fencing & Culture Notes \\
\hline
\end{tabular}


As seen in Table 1, the themes including alphabet, architecture, folklore, literature, philosophy, science and sports that are related to the product dimension were obtained in the textbook of Genki I: an Integrated Course in Elementary Japanese.

The codes including Hiragana, Kanji and Katakana were obtained under the alphabet theme. These codes are located in the "Japanese Writing System" section. Here is a sample part where the Hiragana and Katakana codes were obtained:

Hiragana and Katakana, like the alphabet, represent sounds. As you can see in the above example, hiragana has a roundish shape and is used for conjugation endings, function words, and native Japanese words not covered by kanji. Katakana, which has rather straight lines, is normally used for writing loanwords and foreign names... (Banno, Ikeda, Ohno, Shinagawa \& Tokashiki, 2011, p. 24).

The codes including "Japanese Houses and Shurei Gate on 2,000-yen bill" were obtained under the folklore theme. These codes are located in the "Culture Notes" section. Here is a sample part where the "Japanese Houses" code was obtained:

Traditionally, Japanese buildings were made of wood. Rooms were floored with tatami (rice-straw mats) and divided by fusuma or shooji (two types of sliding doors). Modern Japanese houses have mainly Western-style rooms, and are equipped with Western-style toilets... (Banno et al., 2011, p. 101).

The codes including "Japanese Folktale", "Kabuki Theater", "Puppet Theater", "Humorous Storytelling" and "Masked Musical Drama" were obtained under the architecture theme. The "Japanese Folktale" and "Kabuki Theater" codes are located in "The Folktale Kasajizo" and "The Kabuki and Culture Notes" sections, respectively. Moreover, the codes including "Puppet Theater", "Humorous Storytelling" and "Masked Musical Drama" are located in the "Culture Notes" section. Here is a sample part where the "Kabuki" code was obtained:

Takeshi: Mary, do you like Kabuki?

Mary: Kabuki? I don't know it well. But Robert said it was interesting.

Takeshi: I got two tickets for Kabuki, so would you like to go to see it?

Mary: Sure. When is it?

Takeshi: On Thursday. From twelve noon to four.

... (Banno et al., p. 209).

The "A portrait of Ichiyoo Higuchi on 5,000-yen bill" code was obtained under the literature theme. This code is located in the "Culture Notes" section. Here is a sample part where the "A portrait of Ichiyoo Higuchi on 5,000-yen bill" code was obtained:

A portrait of Ichiyoo Higuchi (1872-1896), a writer and poet (Banno et al., p. 68). The "A portrait of Yukichi Fukuzawa on 10,000-yen bill" code was obtained under the philosophy theme. This code is located in the "Culture Notes" section. Here is a sample part where the "A portrait of Yukichi Fukuzawa on 10,000-yen bill" code was obtained:

A portrait of Yukichi Fukuzawa (1835-1901), a philosopher and the founder of Keio University (Banno et al., p. 68).

The "A portrait of Hideyo Noguchi on 10,000-yen bill" code was obtained under the science theme. This code is located in the "Culture Notes" section. Here is a sample part where the "A portrait of Hideyo Noguchi on 10,000-yen bill" code was obtained:

A portrait of Hideyo Noguchi (1876-1928), a bacteriologist who devoted himself to yellow fever research (Banno et al., p. 68).

The codes including "Sumo Wrestling", "Judo" and "Japanese Fencing" were obtained under the sports theme. These codes are located in the "Culture Notes" section. Here is a sample part where the "Sumo Wrestling" code was obtained:

The parts of the body are explained through the Sumo wrestler visual. (Banno et al., p. 185).

Table 2. Themes and codes of the cultural elements in thought dimension of the culture in Genki I textbook

\begin{tabular}{l|l}
\hline Genki I: An Integrated Course in Elementary Japanese \\
\hline Themes and Codes & Themes and Codes by the Textbook Section \\
\hline Respect & Section including Respect Theme \\
Bowing & Culture Notes \\
\hline Faith & Section including Faith Theme \\
Religious days & The Folktale Kasajizo \\
Visit to the Buddhist temple & Culture Notes \\
\hline
\end{tabular}

As seen in the table 2, the "bowing" code was obtained under the respect theme. This code is located in the "Culture Notes" section. Here is a sample part where the "bowing" code was obtained: 
Japanese people greet each other by bowing, which has many other functions, such as expressing respect, gratitude, or apologies. Three different eays of bowing, ranging from a small nod of the head to a 45-degree bend at the waist... (Banno et al., p. 37).

The codes including "Religious days" and "Visit to the Buddhist temple" were obtained under the faith theme. These codes are located in "the Folktale Kasajizo" and "the Culture Notes" sections, respectively. Here is a sample part where the "Visit to the Buddhist temple" code was obtained:

Many people go to Shinto Shrines and Buddhist temples... (Banno et al., p. 264).

Table 3. Themes and codes of the cultural elements in behavior dimension of the culture in Genki I textbook

\begin{tabular}{|c|c|}
\hline \multicolumn{2}{|c|}{ Genki I: An Integrated Course in Elementary Japanese } \\
\hline Themes and Codes & Themes and Codes by the Textbook Section \\
\hline Customs & Section including Customs Theme \\
\hline Greeting in Japanese culture & Culture Notes \\
\hline Naming in Japanese culture & Culture Notes \\
\hline Tea ceremony & Culture Notes \\
\hline Flower arrangement & Culture Notes \\
\hline Calligraphy & Culture Notes \\
\hline New year in Japan & Culture Notes \\
\hline Education & Section including Education Theme \\
\hline Japanese Education System & Culture Notes \\
\hline Festivals & Section including Festivals Theme \\
\hline The Sapporo Snow Festival & Culture Notes \\
\hline The Kyoto Gion Festival & Culture Notes \\
\hline The Aomori Nebuta Festival & Culture Notes \\
\hline The Tokushima Awa Dance Festival & Culture Notes \\
\hline The Sendai Tanabata Festival & Culture Notes \\
\hline Foods and Drinks & Section including Foods and Drinks Theme \\
\hline Beef rice bowl & Culture Notes \\
\hline Black beans & Culture Notes \\
\hline Buckwheat noodles & Culture Notes \\
\hline Curry with rice & Culture Notes \\
\hline Deep-fried shrimp & Culture Notes \\
\hline Dumplings & Culture Notes \\
\hline Hamburger steak & Culture Notes \\
\hline Herring roe & Culture Notes \\
\hline Natto & Grammar \\
\hline Ramen noodles & Culture Notes \\
\hline Raw seafood & Culture Notes \\
\hline Rice cake & Culture Notes \\
\hline Sake & Practice \\
\hline Savory pancake & Culture Notes \\
\hline Spaghetti & Culture Notes \\
\hline Sushi & Practice \\
\hline Tempura & Practice \\
\hline Tonkatsu & Shopping \\
\hline Udon noodles & Culture Notes \\
\hline Leisure & Section including Leisure Theme \\
\hline Kinship terms & Culture Notes \\
\hline Climate in Japan & Culture Notes \\
\hline National holidays in Japan & Culture Notes \\
\hline Use of the Latin alphabet in everyday life & Japanese Writing System \\
\hline Phone number & Expression Notes \\
\hline Transportation & Culture Notes \\
\hline Yen's value & Culture Notes \\
\hline Time period & Practice \\
\hline Tourism & Section including Tourism Theme \\
\hline Text promoting Okinawa & A Trip to Okinawa \\
\hline Text visualizing Okinawa & A Trip to Okinawa \\
\hline Map of the Cultural Centers & Map of Japan \\
\hline
\end{tabular}


As seen in the table 3, the codes including "Greeting in Japanese culture", "Naming in Japanese culture", "Tea ceremony", "Flower arrangement", "Calligraphy" and "New year in Japan" were obtained under the customs theme. These codes in question are located in the "Culture Notes" section. Here is a sample part where the "Naming in Japanese culture" code was obtained: When Japanese give their name, they say their family name first and given name last (middle names do not exist). When introducing themself, they often say only their family name. Here are some typical Japanese names... (Banno et al., p. 45).

The "Japanese Education System" code was obtained under the education theme. This code is located in the "Culture Notes" section. Here is a sample part where the "Japanese Education System" code was obtained:

Most children in Japan attend kindergartens or nursery schools before entering elementary school. Compulsory education comprises six years of elementary school and three years of junior high school. Although not compulsory, over 95\% of junior high students go on to high school for three years... (Banno et al., p. 154).

The codes including “The Sapporo Snow Festival", "The Kyoto Gion Festival”, "The Aomori Nebuta Festival”, "The Tokushima Awa Dance Festival" and "The Sendai Tanabata Festival" were obtained under the festivals theme. These codes in question are located in the "Culture Notes" section. Here is a sample part where the "Sapporo Snow Festival" code was obtained:

There are many festivals in Japan. Some are famous, while others are known only to the locals. Some are very traditional, while others are rather new. Here are some examples of well-known festivals...The Sapporo Snow Festival is held for a week in early February. It features large snow sculptures constructed in a park on the main avenue (Banno et al., p. 144).

The codes including "Beef rice bowl", "Black beans", "Buckwheat noodles", "Curry with rice", "Deep-fried shrimp", "Dumplings", "Hamburger steak", "Herring roe", "Natto", "Ramen noodles", "Raw seafood", "Rice cake", "Sake", "Savory pancake", "Spaghetti", "Sushi", "Tempura", "Tonkatsu" and "Udon noodles" were obtained under the foods and drinks theme. The codes including "Beef rice bowl", "Black beans", "Buckwheat noodles", "Curry with rice", "Deep-fried shrimp", "Dumplings", "Hamburger steak", "Herring roe", "Ramen noodles", "Raw seafood”, "Rice cake”, "Savory pancake", "Spaghetti" and "Udon noodles" were located in the "Culture Notes" section. The codes including "Sake", "Sushi" and "Tempura" were located in the "Practice" section. The "Map of the Cultural Centers" code is located in the "Map of Japan" section. The "Natto" code is located in the "Grammar" section. The "Tonkatsu" code is located in the Shopping section. Here is a sample part where the "Rice cake" code was obtained:

...The staple food for New Year's is rice cake, which is toasted or served in New Year's soup... (Banno et al., p. 264).

The codes including "Kinship terms", "Climate in Japan", "National holidays in Japan", "Use of the Latin alphabet in everyday life", "Phone number", "Transportation", "Yen's value" and "Time period" were obtained under the leisure theme. The codes including "Kinship terms", "Climate in Japan" and "National holidays in Japan" were located in the "Culture Notes" section. The "Use of the Latin alphabet in everyday life" code is located in the "Japanese Writing System" section. The "Phone number" code is located in the Expression Notes section. The "Time period" code is located in the "Practice" section. The "Time period" code is located in the "Practice" section. Here is a sample part where the "Climate in Japan" code was obtained:

...Winter is sunny and dry on the Pacific coasts, but cloudy and snowy on the Sea of Japan coast. Spring is rather short because daily temperatures rise quickly and the season is cut short by the arrival of the rainy season, which lasts for about a month and a half... (Banno et al., p. 286).

The codes including "Text promoting Okinawa", "Text visualizing Okinawa" and "Map of the Cultural Centers" were obtained under the tourism theme. The codes including "Text promoting Okinawa" and "Text visualizing Okinawa" were located in the "A Trip to Okinawa" section. The "Map of the Cultural Centers" code is located in the "Map of Japan" section. Here is a sample part where the "Text promoting Okinawa" code was obtained:

Takeshi: Robert, thank you for the postcard. Did you enjoy the trip?

Robert: Yes. The sea was very beautiful in Okinawa.

Takeshi: Good. I like the sea very much, too. Was the airline ticket expensive?

Robert: No, it wasn't so expensive. How was your date, Takeshi?

Takeshi:.. (Banno et al., p. 129). 
Table 4. Devices used for the cultural awareness in product dimension of the culture in Genki I textbook

\begin{tabular}{l|l}
\hline Genki I: An Integrated Course in Elementary Japanese \\
\hline Cultural Elements & Devices for Cultural Awareness \\
\hline \multirow{2}{*}{ Alphabet } & $\begin{array}{l}\text { Experiencing culture through language use } \\
\text { Picture }\end{array}$ \\
\hline \multirow{2}{*}{ Architecture } & $\begin{array}{l}\text { Describing and explaining the culture } \\
\text { Picture }\end{array}$ \\
\hline & $\begin{array}{l}\text { Dialogue } \\
\text { Picture } \\
\text { Folklore }\end{array}$ \\
& $\begin{array}{l}\text { Reading text } \\
\text { True/False }\end{array}$ \\
\hline Literature & Picture \\
\hline Philosophy & Picture \\
\hline Science & Picture \\
\hline Sport & Picture \\
\hline
\end{tabular}

As seen in the table 4, the devices used for the creation of cultural awareness in the alphabetical element were detected as the "Experiencing culture through language use" and "Picture". Here is a sample part where the "Experiencing culture through language use" device was used:

...Knji, or Chinese characters, represent not just sounds but also meanings. Mostly,kanji are used for nouns and stems of verbs and adjectives (Banno et al., p. 24).

The devices used for the creation of cultural awareness in the architectural element were detected as "Picture" and "Describing and explaining the culture". Here is a sample visual:

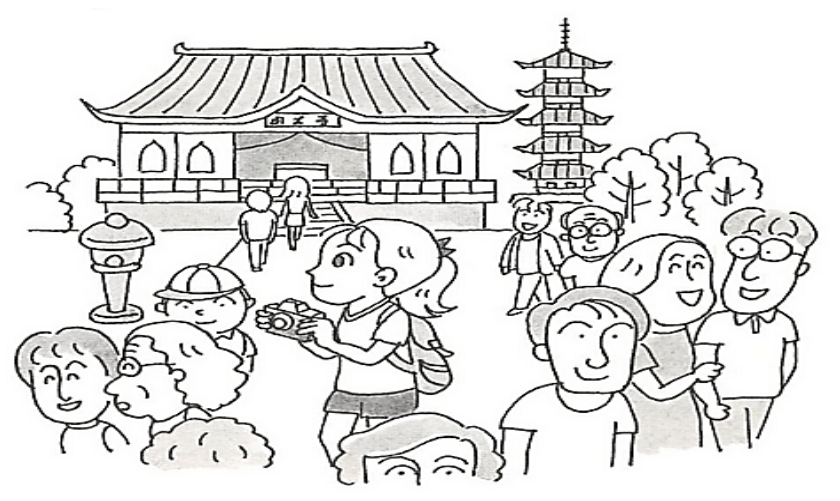

Image 1. The visual used in the dialogue text of "Mary's host family's house" (Banno et al., p. 102).

The devices used for the creation of cultural awareness in the folklore element were detected as "Dialogue", "Picture", "Reading text" and "True/False". Here is a sample visual:

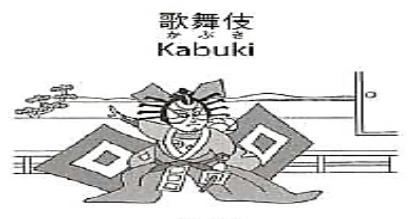

葓語

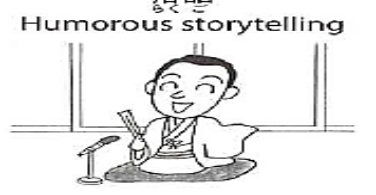

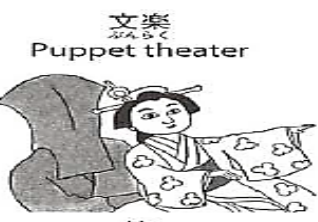

䏍㫐

Masked musical drama

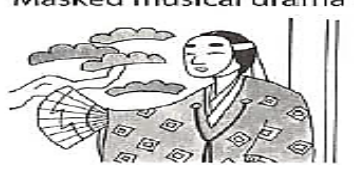

Image 2. The visuals used in the section of "Japanese Traditional" (Banno et al., p. 226).

The "Picture" device was used for the creation of cultural awareness in the Literature, Philosophy, Science and Sports elements. The visual used in the Sport element is presented as follows: 

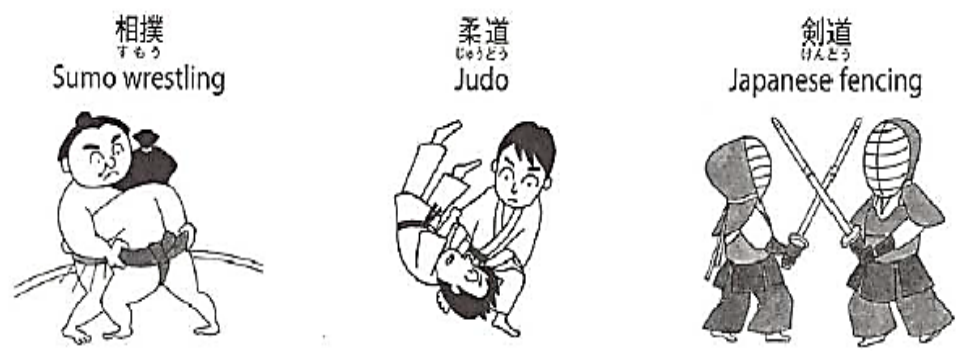

Image 3. The visuals used in the section of "Japanese Traditional" (Banno et al., p. 226).

Table 5. Devices used for the cultural awareness in thought dimension of the culture in Genki I textbook

\begin{tabular}{c|c}
\hline \multicolumn{2}{c}{ Genki I: An Integrated Course in Elementary Japanese } \\
\hline Cultural Elements & Devices for Cultural Awareness \\
\hline Respect & $\begin{array}{c}\text { Describing and explaining the culture } \\
\text { Picture }\end{array}$ \\
\hline Faith & $\begin{array}{c}\text { Describing and explaining the culture } \\
\text { Free writing } \\
\text { Picture }\end{array}$ \\
\hline
\end{tabular}

As seen in the table 5, the devices used for the creation of cultural awareness in the respect element were detected as "Describing and explaining the culture" and "Picture". Here is a sample part where the "Describing and explaining the culture" device was used:

Culture Note: ... When meeting someone in a business situation for the first time, it is customary to exchange meeshi (business cards) with a small bow. Etiquette guides list a vast number of rules and pointers, but just remember that the important thing is to clearly show your respect when exchanging meeshi (Banno et al., p. 37).

The devices used for the creation of cultural awareness in the faith element were detected as "Describing and explaining the culture", "Free writing" and "Picture". Here is a sample part where the "Free writing" device was used:

\section{(II)書<綀翼}

Choose one topic from the list below and write what you do/did on these days.

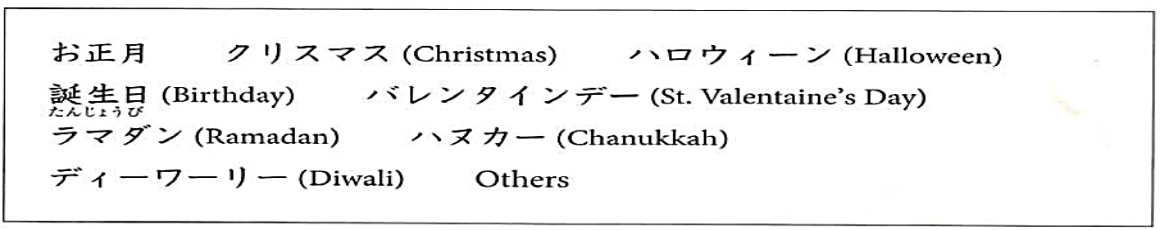

Figure 2. "Free writing" device used in the section of "The Folktale Kasajizo" (Banno et al., p. 339).

Table 6. Devices used for the cultural awareness in behavior dimension of the culture in Genki I textbook

\begin{tabular}{c|c}
\hline \multicolumn{2}{c}{ Genki I: An Integrated Course in Elementary Japanese } \\
\hline Cultural Elements & $\begin{array}{c}\text { Devices for Cultural Awareness } \\
\text { Pescribing and explaining the culture } \\
\text { Picture }\end{array}$ \\
\hline Education & $\begin{array}{c}\text { Describing and explaining the culture } \\
\text { Picture }\end{array}$ \\
\hline Festivals & $\begin{array}{c}\text { Describing and explaining the culture } \\
\text { Picture }\end{array}$ \\
\hline Foods and Drinks & $\begin{array}{c}\text { Describing and explaining the culture } \\
\text { Experiencing culture through language use } \\
\text { Picture } \\
\text { Role play }\end{array}$ \\
\hline Leisure & $\begin{array}{c}\text { Describing and explaining the culture, Picture } \\
\text { Experiencing culture through language use } \\
\text { Footnote } \\
\text { Picture }\end{array}$ \\
\hline Tourism & $\begin{array}{c}\text { Dialogue } \\
\text { Picture }\end{array}$ \\
\hline
\end{tabular}


As seen in the table 6, the devices used for the creation of cultural awareness in the customs element were detected as "Describing and explaining the culture" and "Picture". Here is a sample part where the "Picture" device was used:
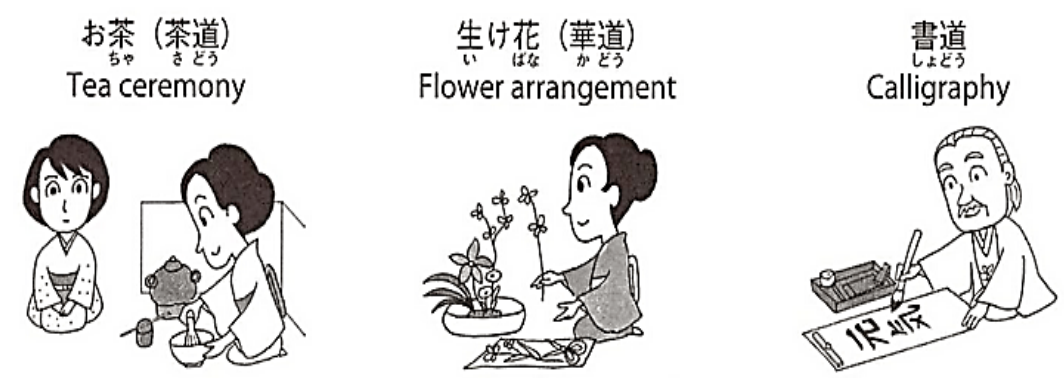

Image 4. The visuals used in the section of "Japanese Traditional" (Banno et al., p. 226).

The devices used for the creation of cultural awareness in the education element were detected as "Describing and explaining the culture" and "Picture". Here is a sample part where the "Picture" device was used:

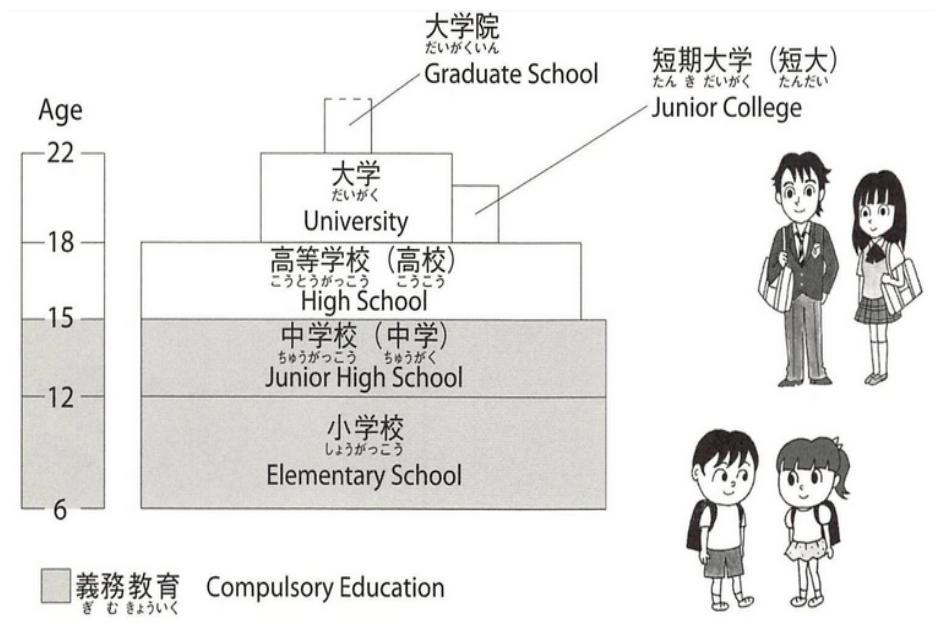

Image 5. The visuals used in the section of "Japan's educational system” (Banno et al., p. 154).

The devices used for the creation of cultural awareness in the festivals element were detected as "Describing and explaining the culture" and "Picture". Here is a sample part where the "Describing and explaining the culture" device was used:

The Aomori Nebuta Festival is held August 2-7. Huge colorful lanterns are pulled through the streets, accompanied by people dancing and playing flutes and drums (Banno et al., p. 144).

The devices used for the creation of cultural awareness in the foods and drinks element were detected as "Describing and explaining the culture", "Experiencing culture through language use", "Picture" and "Role play". Here is a sample part where the "Role play" device was used:

Role Play-One student is a waiter/waitress. The other student goes to a restaurant. Look at the menu below and order some food or drink, using Dialogue II as a model (See Culture Note in Lesson 8 [p. 207] for more information on Japanese food.) (Banno et al., p. 79).

The devices used for the creation of cultural awareness in the leisure element were detected as "Describing and explaining the culture", "Experiencing culture through language use", "Footnote" and "Picture". Here is a sample part where the "Describing and explaining the culture" device was used:

...Summer in most parts of Japan is hot and very humid, and almost tropical in some places. Typhoons make occasional landfalls in summer and early fall (Banno et al., p. 286).

The devices used for the creation of cultural awareness in the tourism element were detected as "Dialogue" and "Picture". Here is a sample part where the "Picture" device was used: 


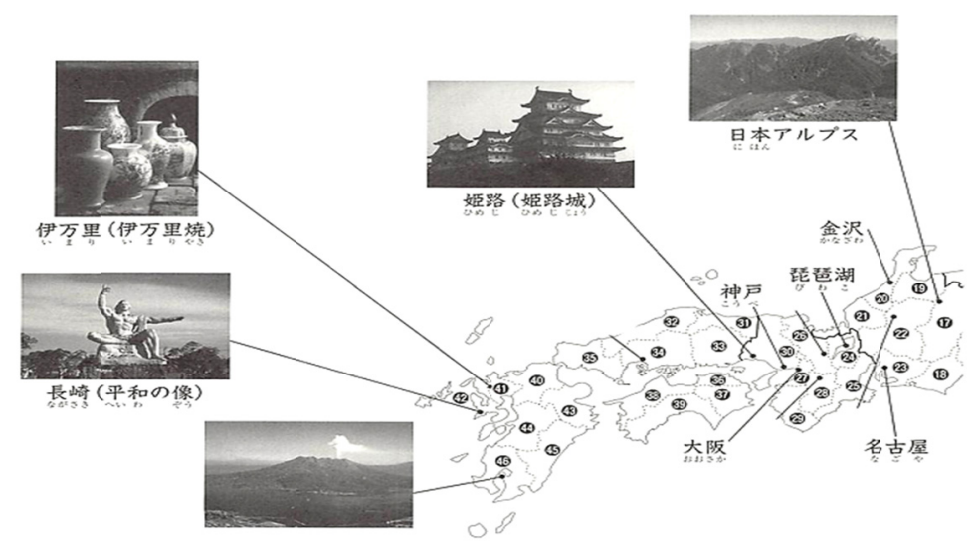

Image 6. Part of the Japanese culture centers map (Banno et al., p. 378)

\section{Conclusion and Discussion}

Genki is one of the popular books to learn Japanese. This study has examined the textbook "Genki I: An Integrated Course in Elementary Japanese" in terms of cultural elements. There are examples of the product, thought and behavior dimensions of the culture in this textbook, and also it consists of a various devices to create cultural awareness. Qu (2010), Peterson \& Coltrane (2003) and Frank (2013) defined the devices to create cultural awareness as follows: cultural collections, web quests, role plays, cultural observations, culture journals, describing and explaining the culture, experiencing culture through language use, dialogue and mini-dramas, authentic materials, proverbs, picture, films, music, songs and dances.

Cultural notes have been added to section ends in the textbook "Genki I: an Integrated Course in Elementary Japanese". Thus, those who want to learn Japanese have the opportunity to gain knowledge about Japanese culture through these cultural notes. However, the Japanese culture was not only included in the cultural notes of the textbook, and the cultural texts on Japanese culture were included in various parts of the textbook as well. From time to time, the textbook also mentions about the cultures other than the Japanese culture. As a result of the examination of the textbook, it has been seen that cultural objects are not conveyed as an imposition on those who want to learn Japanese. Because the textbook does not give detailed information on cultural elements, and different attitudes of different cultures are not displayed. Those who want to learn Japanese through this book can raise their awareness on different dimensions of the culture. The raising awareness of an individual in terms of cultural values or social characteristics of a society does not mean that he/she unquestionably embraces these values and characteristics. On the contrary, these items enable his/her personality to get out of the narrow-frame and gain a more universal structure (Bada, 2000).

The elements including alphabet, architecture, folklore, literature, philosophy, science and sports were determined for the cultural product dimension in the textbook Genki I. These elements are usually found in the "Culture Notes" section as well as rarely in different parts of the textbook (Japanese Writing System, The Folktale Kasajizo, and Kabuki). The "Picture" device is often used to provide cultural awareness for the cultural elements in the product dimension. In addition, the devices including "Experiencing culture through language use", "Describing and explaining culture", "Dialogue", "Reading text" and "True / False" were also used in the textbook. Doğanay (2013) investigated the influence of various cultural activities on language learning, used the applications including games, role-play, dialogue, discussion, target culture and comparison of their own cultures. He used videos and cultural materials in his work, and concluded that cultural practices contribute to language learning in various ways.

The elements of respect and faith regarding the thought dimension of the culture were also determined in the textbook Genki I. These elements are usually found in the "Culture Notes" section, but the faith element is located in the "Folktale Kasajizo" section. The devices including "Describing and explaining the culture", "Picture" and "Free writing" were used to raise cultural awareness in the product dimension of the culture. The activity that the "Free writing" device was used also included cultural elements of different beliefs. So the textbook has the opportunity to appeal to students in different cultures who want to learn Japanese. The textbook proposes to increase the number of such samples for all dimension of the culture. So those who want to learn foreign languages will also learn to respect different cultures. Second language teaching will be wrong and incomplete without the culture. If students do not have any idea on the language or country they are targeted to learn will cause them to become impersonal, insensitive in their second language learning (Genç \& Bada, 2005).

The textbook Genki I has emphasized behavior dimension of the culture, at most. The elements including customs, education, festivals, foods and drink, leisure, tourism were found in the behavior dimension. These elements are usually 
detected in the "Culture Notes" section as well as rarely in different parts of the book (Grammar, Practice, Shopping, Japanese Writing System, Expression Notes, A Trip to Okinawa, Map of Japan). The cultural elements in the "Grammar" section of the textbook is remarkable. Er (2015) found that Turkish language teachers do not make much use of cultural elements in the language teaching process, and also stated that associating the examples given in language lecture courses with culture could save teaching of linguistic knowledge from boredom and bring it to a more meaningful state. Kutlu (2015) asserted that language teaching cannot be limited with teaching linguistic rules and basic skills.

The devices including "Describing and explaining the culture" and "Picture" were mostly used to raise cultural awareness in the behavior dimension of the culture. Moreover, the devices including "Experiencing culture through language use", "Describing and explaining the culture", "role play", "footnote", and "Dialogue" were also found in this dimension. The support of cultural elements with various devices will undoubtedly raise the level of cultural awareness of the student. Saniei (2012) asserts that the development of the student's cultural awareness can make easier for $\mathrm{him} / \mathrm{her}$ to use language in real life.

\section{References}

Akpınar, K. D., \& Mete, F. (2013). Domain of culture in foreign language teachers' competency: a comparison of Turkey and China. Journal of Educational Sciences Research, 3(2), 91-106. https://doi.org/10.12973/jesr.2013.326a

Alyılmaz, C. (2010). Problems of Turkish teaching. Turkish Studies, 5(3), 728-749. https://doi.org/10.7827/TurkishStudies.1629

Bada, E. (2000). Culture in ELT. Çukurova University Journal of Social Sciences, 6(6), 100-110.

Banno, E., Ikeda, Y., Ohno, Y., Shinagawa, C., \& Tokashiki, K. (2011). Genki I: An integrated course in elementary Japanese. Tokyo: The Japan Times.

Byram, M., Gribkova, B., \& Starkey, H. (2002). Developing the Intercultural Dimension in Language Teaching: a practical introduction for teachers. Strasbourg: Language Policy Division, Directorate of School, Out-of-School and Higher Education, Council of Europe.

Çakır, İ. (2006). Developing cultural awareness in foreign language teaching. The Turkish Online Journal of Distance Education, 7(3), 154-161.

Castro, P., \& Sercu, L. (2005). Objectives of foreign language teaching and culture teaching time. In L. Sercu (Ed.), Foreign language teachers and intercultural competence: an international investigation (pp. 19-38). Clevedon: Multilingual Matters.

Cortazzi, M., \& Jin, L. (2000). Cultural mirrors: Materials and methods in the EFL classroom. In E. Hinkel (Ed.), Culture in second language teaching and learning, (pp. 196-219). Cambridge: Cambridge University Press.

Doğanay, Y. (2013). The impact of cultural based activities in foreign language teaching at upper-intermediate (B2) level. Education Journal, 2(4), 108-113. https://doi.org/10.11648/j.edu.20130204.11

Er, O. (2015). Investigation of Turkish teaching applications for foreigners in terms of creating cultural awareness (Unpublished doctoral dissertation). Atatürk University, Erzurum, Turkey.

Frank, J. (2013). Raising Cultural Awareness in the English Language Classroom. English Teaching Forum, 4, 2-11.

Genç, B., \& Bada, E. (2005). Culture in language learning and teaching. The Reading Matrix, 5(1), 73-84.

Kutlu, A. (2015). The use of culture as a tool to teach Turkish for foreigners: The example of Turkish instruction set for foreigners (B1-B2 level). K. Ü. Kastamonu Ĕ̈itim Dergisi, 23(2), 697-710

Merriam, S. B. (2013). Qualitative Research: A Guide to Design and Implementation. (S. Turan, Translation Ed.). Ankara: Nobel Publication.

Mert, O., Alyılmaz, S., Bay, E., \& Akbaba, S. (2009). A study on the comprehention level of the candidate lecturers regarding the social values on the Orkhun inscriptions. The Journal of International Social Research, 2(9), 279-287.

Miles, M. B., \& Huberman, A. M. (1994). Qualitative data analysis. London: Sage Publication.

Nguyen, T. T. T. (2017). Integrating Culture into Language Teaching and Learning: Learner Outcomes. The Reading Matrix: An International Online Journal, 17(1), 145-155.

Peterson, E., \& Coltrane, B. (December, 2003). Culture in second language teaching. ERIC Digest, http://www.cal.org/resources/digest/0309peterson.html 
Qu, Y. (2010). Culture understanding in foreign language teaching. English Language Teaching, 3(4), 58-61. https://doi.org/10.5539/elt.v3n4p58

Salazar, E. Z., \& Carballo, O. C. (2011). Teaching culture in the foreign language classroom: A reflective model. Revista de Lenguas Modernas, 14, 283-303.

Saniei, A. (2012). Developing cultural awareness in language instructional materials. International Conference on Language, Medias and Culture IPEDR, 33, 10-15.

Tomalin, B., \& Stempleski, S. (1993). Cultural awareness. Oxford: Oxford University Press.

Vrbová, L. (2006). Developing cultural awareness in ELT (Unpublished M.A. Thesis). University of Pardubice, Czech Republic.

Wang, C. (2006). On Chinese culture curriculum planning. International Education Journal, 7(4), 570-579.

Wierzbicka, A. (2006). English: meaning and culture. New York: Oxford University Press. https://doi.org/10.1093/acprof:oso/9780195174748.001.0001

Yıldırım, A., \& Şimşek, H. (2008). Qualitative Research Methods in Social Sciences. Ankara: Seçkin Publication.

\section{Copyrights}

Copyright for this article is retained by the author(s), with first publication rights granted to the journal.

This is an open-access article distributed under the terms and conditions of the Creative Commons Attribution license which permits unrestricted use, distribution, and reproduction in any medium, provided the original work is properly cited. 